\title{
Forensic Medical Study of Road Traffic Accident Cases Admitted to Minia University Hospital
}

\author{
Rehab H. A. Younis ; Rana Adel ${ }^{1}$
}

\begin{tabular}{ll}
\hline & ABSTRACT \\
\cline { 2 - 3 } $\begin{array}{l}\text { KEYWORDS } \\
\text { Road traffic accident, } \\
\text { Egypt, }\end{array}$ & $\begin{array}{l}\text { Road traffic accidents (RTAs) constitute a significant public health problem, } \\
\text { they are rising in an alarming rate and causing increased morbidity and mortality } \\
\text { Injuries, } \\
\text { Deaths. }\end{array}$ \\
$\begin{array}{l}\text { road traffic accidents cases in Minia University Hospital from January to December } \\
\text { 2016. The data was obtained from sheets of road traffic accident cases enrolled to the } \\
\text { hospital within the year } 2016 \text { and statistically analyzed as regard the age groups and } \\
\text { sex distribution, the causal vehicle, the pattern of injuries occurred, seasonal } \\
\text { variation, and the number of deaths due to RTA, the leading causes of death and the } \\
\text { survival period following the accident. The total number of studied cases was } 370 ; \\
\text { most of the injuries were observed in adults (74.3\%), with marked increase in males } \\
\text { (79.5\%). Four wheels were the most causal vehicles (58.9\%) for RTAs with higher } \\
\text { incidence in spring. Bone fractures were the most common injury pattern (60.5 \%) } \\
\text { followed by head injuries (37.6\%), then abdominal injuries (9.7\%), and finally chest } \\
\text { injuries (8.4\%). Skin injuries were observed only in (27.8\%) of cases. The total } \\
\text { number of deaths was } 126 \text { (34.1\%) cases. Range of survival period was 0-11 days; the } \\
\text { most frequent injury presented in dead cases was head injuries (69.8\%). The present } \\
\text { study concluded that bone fractures were the most common injury pattern in RTAs } \\
\text { while head injuries were the main contributing factor for death. The skin injury is } \\
\text { not indicative of severity of internal injury. }\end{array}$ \\
\hline
\end{tabular}

\section{Introduction}

Road traffic accidents (RTAs) are a major cause of global mortality and morbidity. Road traffic accidents are conceived to become the $3^{\text {rd }}$ contributor to global disease burden by 2020. According to the WHO road traffic injuries caused an estimated 1.36 million deaths worldwide in the year 2016 (WHO, 2018). The threat of this public health problem is most pronounced in low- and middleincome countries where $90 \%$ percent of the world's road traffic fatalities take place; also the developing countries tolerate a large

\footnotetext{
${ }^{(1)}$ Forensic Medicine and Clinical Toxicology

Department, Faculty of Medicine, Minia University,

Minia, Egypt.

Corresponding author: E-mail address:

rehab.abdelkareem@mu.edu.eg Tel: 01003611707.
}

proportion of burden and account for about $85 \%$ of the deaths (Peden and Sminkey, 2004). Unfortunately, traffic accidents cause unexpected severe injuries of internal organs despite tiny injuries observed on the external body (Nishitani et al., 2009). Even non-fatal injuries result in increased medical expenditure due to disabilities especially if associated with young adult age group (Chitme et al., 2015). There is marked variation across the world in the way that roads are used and the resulting injuries which will have important modulations for road safety policy and practice in each country (Nantulya and Reich, 2002).

In Egypt, World Health Organization (WHO) estimates that about 12000 persons were lost per year due to road traffic crashes. 
In addition it has a road traffic fatality rate of 42 deaths per 100000 population (WHO, 2018). Also, traffic accidents in Egypt create a massive economic burden as they cost 52 billion Egyptian Pounds (about \$US 6.6 billion) for the year 2014 (Abdallah et al., 2016). Ismail and Abdelmageed (2010) revealed that Egypt could lose up to 11.8 billion Egyptian Pounds (about \$US 2.1 billion) per year because of road traffic accidents only leading to a serious impact on the national economy.

Motor-vehicle accidents are complex events resulting primarily from human, technical, and environmental contributing factors. Increase in the number of motor vehicles, continuous growth in population, as well as excessive speeding and use of alcohol and other addictive drugs either narcotic or addictive are the major factors that influence the frequency and severity of motor-vehicle collisions in Egypt. Identification of the most probable factors that affect the occurrence of accidents is essential for effective road traffic accident prevention, increase the income and consequently improve welfare (Emaraa et al., 2015).

The present study was carried out to determine the patterns and the incidence of injuries amongst RTA victims brought to Minia University Hospital from January to December 2016, Minia, Egypt.

\section{Subjects and Methods}

This retrospective study included cases with road traffic accidents who were admitted to Minia University Hospital from January till December 2016, after permission from Minia University Hospital. Data collected were used only for scientific research without clarifying the names or identity number of patients.

The data was collected from cases sheets present in medical record section of Minia University Hospital. Cases with incomplete records were excluded from the study. Data included age, sex, causal vehicle, season, pattern of injuries occurred, number of deaths, leading cause of death and the survival period following the accident.

\section{Statistical analysis}

The collected data were coded, tabulated and statistically analyzed using Statistical Package for Social Sciences (SPSS for windows, version 20). Descriptive statistics were done for parametric quantitative data by means, standard deviation, and maximum of the range, while they were done for categorical data by number and percentage. Analyses were done for qualitative data using Chi square test. The level of significance was taken at $(\mathrm{p}<$ 0.05). Simple and multiple binary logistic regression analysis were performed for prediction of mortality.

\section{Results}

The total number of the studied cases was 370 patients with complete medical report. Twenty three cases were excluded due to incomplete records. The results of this study revealed that males were the commonest represented $294(79.5 \%)$ cases and females represented $76(20.5 \%)$ cases. The mean age was $32.21 \pm 17.45$ years, where most of RTA cases were in adults counted for 275 (74.3\%). 
Then teenage came in second order 41 cases (11.1\%), followed by the child group where 36 cases $(9.7 \%)$ were observed. Finally, the elderly group constituted the least number of cases $18(4.9 \%)$ as shown in table (1).
Concerning the seasonal variation, the maximum number of RTA cases was observed in spring $143(38.6 \%)$ cases, while the least number of RTA cases was in autumn 46 $(12.4 \%)$ cases as shown in table (1).

Table (1): Distribution of age, sex, season, vehicle type, outcome and survival period in road traffic accidents cases $(n=370)$.

\begin{tabular}{|c|c|}
\hline Item & Descriptive statistics \\
\hline \multicolumn{2}{|l|}{ Age } \\
\hline Range & $(1-88)$ \\
\hline Mean \pm SD & $32.21 \pm 17.45$ \\
\hline \multicolumn{2}{|l|}{ Age groups } \\
\hline Child (1-12) & $36(9.7 \%)$ \\
\hline Teenage (12-18) & $41(11.1 \%)$ \\
\hline Adult (18-65) & $275(74.3 \%)$ \\
\hline Elderly $(>65 y)$ & $18(4.9 \%)$ \\
\hline \multicolumn{2}{|l|}{ Sex } \\
\hline Male & $294(79.5 \%)$ \\
\hline Female & $76(20.5 \%)$ \\
\hline \multicolumn{2}{|l|}{ Season } \\
\hline Winter & $90(24.3 \%)$ \\
\hline Spring & $143(38.6 \%)$ \\
\hline Summer & $91(24.6 \%)$ \\
\hline Autumn & $46(12.4 \%)$ \\
\hline \multicolumn{2}{|l|}{ Vehicle type } \\
\hline Four wheels & $218(58.9 \%)$ \\
\hline Two-wheels & $125(33.8 \%)$ \\
\hline Three-wheels & $27(7.3 \%)$ \\
\hline \multicolumn{2}{|l|}{ Outcome } \\
\hline Live & $244(65.9 \%)$ \\
\hline Dead & $126(34.1 \%)$ \\
\hline \multicolumn{2}{|l|}{ Survival Period } \\
\hline Range & $(0-11)$ \\
\hline Mean \pm SD & $3.76 \pm 3.02$ \\
\hline
\end{tabular}


As regard type of offending vehicle, four wheels (private cars, buses, minibuses, trucks) were the most causal vehicles 218 (58.9\%), followed by two-wheels 125 (33.8\%), while three-wheels were the least $27 \quad(7.3 \%)$ offending vehicle in RTA. The total numbers of RTAs deaths were $126(34.1 \%)$ cases; the range of survival period was 0-11 days with mean \pm SD was $(3.76 \pm 3.02)$ as shown in table (1). Eighty cases survived for 1-5 days, followed by 34 cases survived for less than 24 hours, while 12 cases survived for 5-11 days as shown in figure (1).

\section{Period of survival before death}

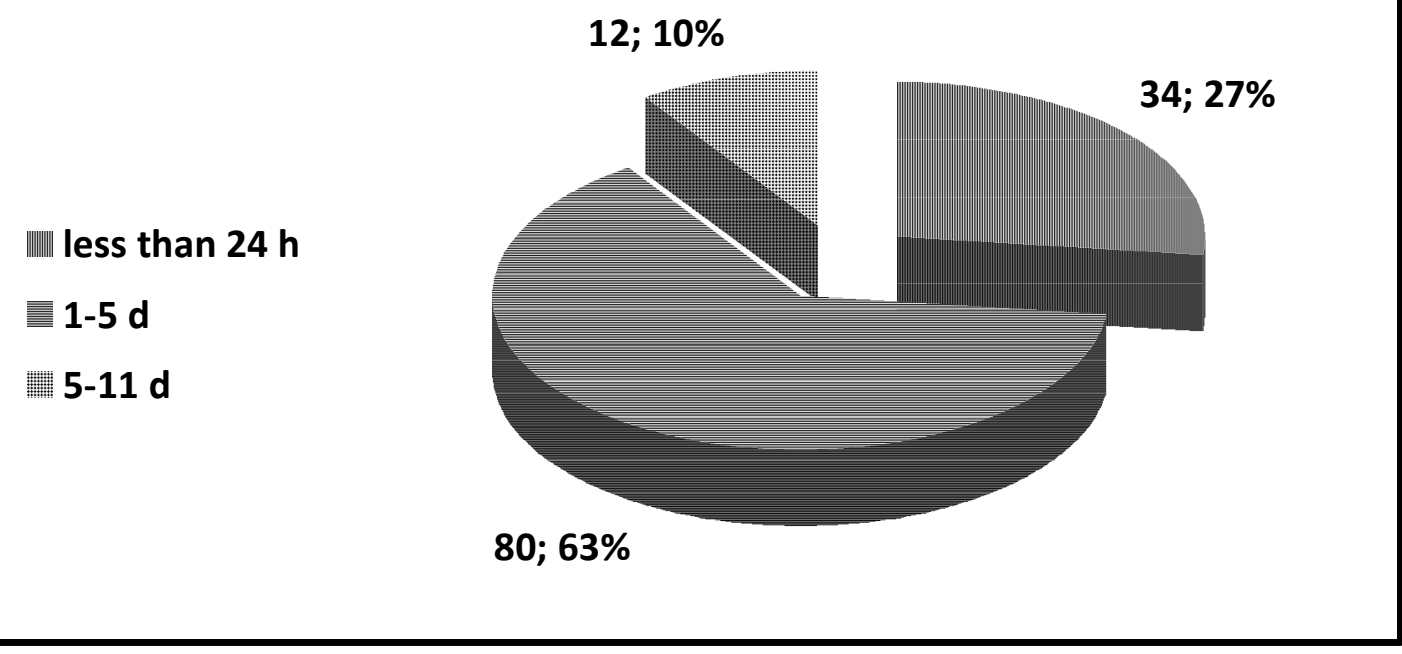

Fig. (1): Period of survival of road traffic accidents cases $(n=126)$.

Table (2) showed the types of injuries in RTA cases, bone fractures were the most common injuries occurred in $224(60.5 \%)$ cases with higher incidence of lower limb fractures in 124 cases. Head injuries were observed in $139(37.6 \%)$ cases, abdominal injuries occurred in $36(9.7 \%)$ cases, chest injuries were presented in $31(8.4 \%)$ cases and skin injuries were found in $103(27.8 \%)$ cases.

Combined injuries were present in 156 cases; their distribution was illustrated in figure (2).

Table (2): Pattern of different injuries in road traffic accidents $(n=370)$.

\begin{tabular}{|l|c|}
\hline \multicolumn{1}{|c|}{ Type of injury } & Number \& Percentage \\
\hline Bone fractures & $224(60.5 \%)$ \\
Lower limb fractures & $124(33.5 \%)$ \\
Upper limb fractures & $51(13.8)$ \\
Trunk fractures & $26(7 \%)$ \\
Combined & $23(6.2 \%)$ \\
\hline Head injuries & $139(37.6 \%)$ \\
\hline Abdominal injuries & $36(9.7 \%)$ \\
\hline Chest injuries & $31(8.4 \%)$ \\
\hline Skin lesions & $103(27.8 \%)$ \\
\hline
\end{tabular}




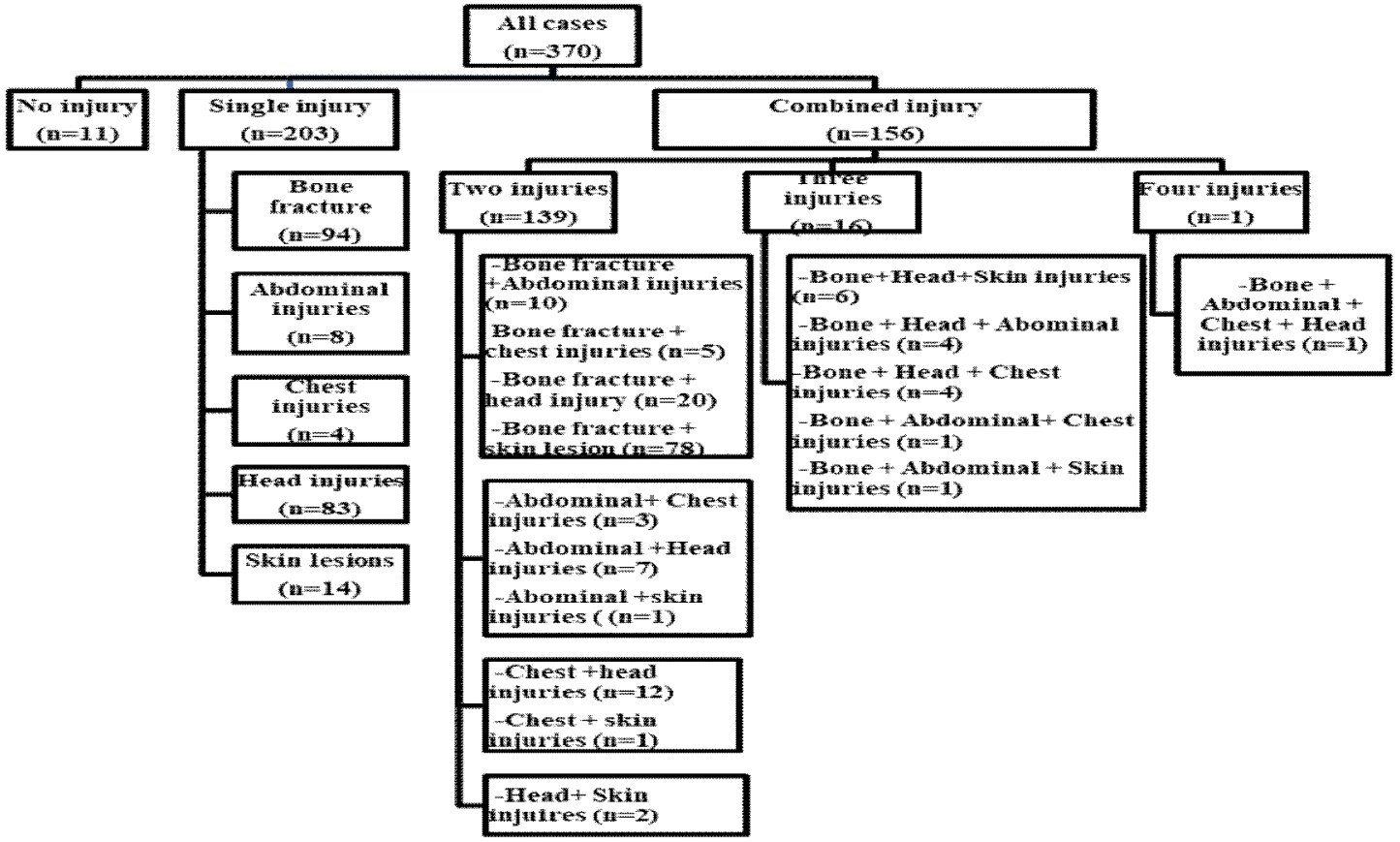

Fig. (2): Combined injuries distribution.

The commonest presenting injuries found in deaths were due to head injuries 88 $(69.8 \%)$, followed by bone fractures 30 (23.8\%), then abdominal injuries 23 (18.3\%), then chest injuries $21(16.7 \%)$ as shown in table (3).

Table (4) showed simple logistic regression analysis for prediction of mortality and revealed that head injuries, chest injuries, abdominal injuries and type of vehicle could predict mortality (odds ratio $>1$ ).

Using multiple logistic regression analysis showed that the most significant factor predicting fatality was head injuries, followed by abdominal injuries, chest injuries and lastly vehicle type as demonstrated in table (5).

Table (3): Relation between injuries and outcome.

\begin{tabular}{|c|c|c|c|}
\hline & \multicolumn{2}{|c|}{ Outcome } & \multirow{2}{*}{ p value } \\
\hline & Live $(n=244)$ & $\operatorname{Dead}(n=126)$ & \\
\hline $\begin{array}{l}\text { Bone fracture } \\
\text { No } \\
\text { Yes }\end{array}$ & $\begin{array}{c}50(20.5 \%) \\
194(79.5 \%)\end{array}$ & $\begin{array}{l}96(76.2 \%) \\
30(23.8 \%)\end{array}$ & $<0.001 *$ \\
\hline $\begin{array}{l}\text { Abdominal injuries } \\
\text { No } \\
\text { Yes }\end{array}$ & $\begin{array}{r}231(94.7 \%) \\
13(5.3 \%)\end{array}$ & $\begin{array}{c}103(81.7 \%) \\
23(18.3 \%)\end{array}$ & $<0.001 *$ \\
\hline $\begin{array}{l}\text { Chest injuries } \\
\text { No } \\
\text { Yes } \\
\end{array}$ & $\begin{array}{c}234(95.9 \%) \\
10(4.1 \%) \\
\end{array}$ & $\begin{array}{l}105(83.3 \%) \\
21(16.7 \%) \\
\end{array}$ & $<0.001 *$ \\
\hline $\begin{array}{l}\text { Head injuries } \\
\text { No } \\
\text { Yes }\end{array}$ & $\begin{array}{l}193(79.1 \%) \\
51(20.9 \%)\end{array}$ & $\begin{array}{l}38(30.2 \%) \\
88(69.8 \%)\end{array}$ & $<0.001 *$ \\
\hline $\begin{array}{l}\text { Skin lesions } \\
\text { No } \\
\text { Yes } \\
\end{array}$ & $\begin{array}{l}152(62.3 \%) \\
92(37.7 \%)\end{array}$ & $\begin{array}{c}115(91.3 \%) \\
11(8.7 \%) \\
\end{array}$ & $<0.001 *$ \\
\hline
\end{tabular}

*Level of significance at $\mathrm{p}<0.05$. 
Table (4): Simple logistic regression analysis for prediction of mortality.

\begin{tabular}{|c|c|c|c|}
\hline & OR & $95 \% \mathrm{CI}$ & P value \\
\hline $\begin{array}{l}\text { Vehicle type } \\
2 \text { or } 3 \text { wheels } \\
4 \text { wheels } \\
\end{array}$ & $\begin{array}{l}\text { Ref. } \\
2.68\end{array}$ & $1.67-4.29$ & $<0.001 *$ \\
\hline $\begin{array}{l}\text { Bone fracture } \\
\text { No } \\
\text { Yes }\end{array}$ & $\begin{array}{l}\text { Ref. } \\
0.08\end{array}$ & $0.05-0.13$ & $<0.001^{*}$ \\
\hline $\begin{array}{l}\text { Abdominal injuries } \\
\text { No } \\
\text { Yes }\end{array}$ & $\begin{array}{l}\text { Ref. } \\
3.97\end{array}$ & $1.93-8.14$ & $<0.001 *$ \\
\hline $\begin{array}{l}\text { Chest injuries } \\
\text { No } \\
\text { Yes } \\
\end{array}$ & $\begin{array}{l}\text { Ref. } \\
4.68 \\
\end{array}$ & $2.13-10.29$ & $<0.001 *$ \\
\hline $\begin{array}{l}\text { Head injuries } \\
\text { No } \\
\text { Yes } \\
\end{array}$ & $\begin{array}{l}\text { Ref. } \\
8.76\end{array}$ & $5.37-14.3$ & $<0.001 *$ \\
\hline $\begin{array}{l}\text { Skin lesions } \\
\text { No } \\
\text { Yes }\end{array}$ & $\begin{array}{l}\text { Ref. } \\
0.16\end{array}$ & $0.08-0.31$ & $<0.001^{*}$ \\
\hline
\end{tabular}

OR: Odds Ratio, CI: confidence interval, Ref.: reference, *level of significance at $\mathrm{p}<0.05$.

Table (5): Multiple logistic regression analysis for prediction of mortality.

\begin{tabular}{|l|c|c|c|}
\hline & OR & $\mathbf{9 5 \%}$ CI & p value \\
\hline Vehicle type & Ref. & & \\
2 or 3 wheels & 3.84 & $2.12-6.97$ & $<0.001^{*}$ \\
4 wheels & & & \\
\hline Abdominal injuries & Ref. & & \\
No & 6.69 & $2.97-15.08$ & $<0.001^{*}$ \\
Yes & Ref. & & \\
\hline Chest injuries & 4.46 & $1.74-11.42$ & $0.002^{*}$ \\
No & & & \\
Yes & Ref. & & \\
\hline Head injuries & 11.52 & $6.59-20.15$ & $<0.001^{*}$ \\
No & & & \\
Yes & & & \\
\hline
\end{tabular}

OR: Odds Ratio, CI: confidence interval, Ref.: reference, ${ }^{*}$ level of significance at $\mathrm{p}<0.05$. 


\section{Discussion}

Road traffic accident is a major worldwide problem which leads to both morbidity and mortality. In Egypt, 8211 road traffic deaths were recorded in 2016 according to WHO report (WHO, 2018). However, few published researches concerned with analysis of types of injury and severity, therefore, the present study assessed the patterns of injuries in road traffic accident cases, the type of causal vehicles, outcomes among patients admitted to Minia University Hospital.

The results of the present study revealed that most of the injured were males $(79.5 \%)$ while females were $20.5 \%$, because men spend more time outside home, in addition to the higher number of male drivers in comparison to females. Some men have aggressive behavior during driving and tend to enjoy with high speed driving. The same findings were observed by other studies (Salgado and Colombage, 1988; Henriksson et al., 2001; Jha and Agrawal, 2004; Emaraa et al., 2015).

The mean age of studied cases were 32 years which is consistent with that revealed by Patil et al. (2008) and Hijar et al. (2003). Adults had higher incidence of RTA $(74.3 \%)$ as it represents the most active phase of life, these results are consistent with other researches in different countrie (Hand and Dhattarwal, 2004; Meel, 2007). This is a serious finding because youth injury and death have a great burden on community as youth stage of life is the most productive period. Other age groups as teenage, children showed lower incidence of RTA as they get great care by their parents and not allowed to drive, while old age had the least incidence due to low mobility of the individuals in this age range.
The highest number of RTA cases in this study occurred during spring as this is the season of exams in Egypt; this coincides with Siddaramanna and Kumar (2014) in Karnataka, India, but disagrees with Kumar et al. (2014) who reported that most of RTA occurred in rainy seasons in Dehradun, India. As regard type of vehicle, four wheels occupied the highest rate of RTA in our study followed by two-wheeler and the least rate was for three-wheeler. These results are in the same line with that of Eke and Frcsed (2001) and Al-Thaifani et al (2016) but this is contradictory to Kanchan et al. (2012) and Siddaramanna \& Kumar (2014) who reported that two-wheeler have a maximum case fatality for accidents in India as it is common mode of transportation there.

Bone fractures were the most common injury pattern $(60.5 \%)$ followed by head injuries $(37.6 \%)$, this is in agreement with results of Emaraa et al. (2015) in Libya, however this disagree with Shotar et al. (2014) study in Jordan who showed that wounds were the commonest presenting injuries. Regarding detailed analysis of bone fractures, lower limb fractures had the highest incidence followed by upper limb fractures, and finally trunk fractures. These findings were consistent with studies done in India (Singh et al., 2014), Iran (Mahdian et al., 2017) and Libya (Emaraa et al., 2015). The higher incidence of lower limb fracture may be attributed to weight bearing function during collision (Cohen et al., 2016).

In the present study, skin injuries were found in only $27.8 \%$ of cases which is an important observation with forensic implication. Skin structure is characterized by high elasticity giving it the ability to mobilize with blunt trauma in contrast to internal organs. So, serious internal injury could be found without corresponding skin injury, this sign is called Casper's sign (Byard, 2012). That is why full medicolegal investigations should be done in 
every case of trauma even in absence of significant skin injury.

The total number of deaths in the present work was $126(34.1 \%)$ cases. The range of survival period was 0-11 days, this disagrees with Kanchan et al. (2012) who revealed long survival period of more than 30 days this may be attributed to the availability of a vast network of hospitals both in public and private sectors with good emergency services in India as mentioned by the authors. The most frequent injury presented in dead cases was head injuries 88 (69.8\%). Bone fractures $30(23.8 \%)$, and thoraco-lumbar injuries were the other common injuries found which agree with Kanchan et al. (2012) and Emaraa et al. (2015).

Regarding prediction of mortality, the results revealed that head injuries, chest injuries, abdominal injuries and type of vehicle could predict fatality. These direct the attention to the importance of early and high quality care and intervention with these cases.

The current study has some limitations related to the incomplete background information concerning the victims as they were not known if they were passengers, drivers or pedestrians. Also alcohol or drug intake was not investigated. The permanent infirmity left and severity of injuries were not documented, this added another limitation.

\section{Conclusions}

The present study concluded that most RTA cases occurred in spring (38.6\%). Four wheels were the most causal vehicles $(58.9 \%)$. Bone fractures were the most common injuries occurred $(60.5 \%)$. The total numbers of deaths were $126(34.1 \%)$ cases and head injuries were the main contributing factor for death. The skin injury is not indicative of severity of internal injury.

\section{Recommendations}

It is necessary to improve the quality of data concerning road traffic injuries through the implementation of a road traffic accident database as well as through injury surveillance in hospitals. Strict enforcement of laws regarding driving of vehicles, wearing of helmets, applying seat belts and alcohol or drug consumption during driving are needed. Strengthening of the health facilities for the victims and improving emergency medical services may decrease deaths and disabilities caused by road traffic collisions.

\section{References}

Abdallah, N.M.; El Hakim, A.S.; Wahdan, A.H.; et al. (2016): "Analysis of accidents cost in Egypt using the willingness-to-pay method". International Journal of Traffic and Transportation Engineering, 5(1):10-18.

Al-Thaifani, A.A.; Al-Rabeei, N.A. and Dallak, A.M. (2016): "Study of the injured persons and the injury pattern in road traffic accident in Sana'a city, Yemen". Advances in Public Health, 1-5.

Byard, R.W. (2012): "How reliable is external examination in identifying internal injuries - Casper's sign revisited". J. Forensic Leg Med., 19(7):419-421.

Chitme, H.R.; Al Harbi, M. and Al Saadi, T.S.N. (2015): "Pattern of road traffic accident injuries in young adults". World Journal of Pharmaceutical Research, 4(4):313-323. 
Cohen, H.; Kugel, C.; May, H.; et al. (2016): "The impact velocity and bone fracture pattern: Forensic perspective". Forensic Sci. Int., 266:54-62.

Eke, N. and Fresed, F. (2001): "Road traffic accidents in the developing word: who are liable"? Anil Aggrawal's Internet Journal of Forensic Medicine and Toxicology, 2(1):14.

Emaraa, A.M.; Greiwb, A.S.H. and Hassana, N.A. (2015): "Pattern of road traffic injuries in patients admitted to Al-jlaa Hospital, Benghazi, Libya". Tanta Medical Journal, 43(2):39-45.

Hand, H.S. and Dhattarwal, S.K. (2004): "Pattern and distribution of injuries in fatal road traffic accidents in Rohtak (Haryana)". Journal of Indian Academy of Forensic Medicine, 26(1):20-23.

Henriksson, E.; Oström, M. and Eriksson, A. (2001): "Preventability of vehiclerelated fatalities". Accid. Anal. Prev., $33: 467-475$.

Híjar, M.; Vazquez-Vela, E. and ArreolaRisa, C. (2003): "Pedestrian traffic injuries in Mexico: a country update". Inj. Control Saf. Promot., 10(1-2):37-43.

Ismail, M.A. and Abdelmageed, S.M.M. (2010): "Cost of road traffic accidents in Egypt". World Academy of Science, Engineering and Technology, 42:1308-1314.

Jha, N. and Agrawal, C.S. (2004): "Epidemiological study of road traffic accident cases: a study from Eastern Nepal". Regional Health Forum WHO South-East Asia Region, 8:15-22.

Kanchan, T.; Kulkarni, V.; Bakkannavar, S.M.; et al. (2012): "Analysis of fatal road traffic accidents in a coastal township of south India". Journal of Forensic and Legal Medicine, 19:448e451e.

Kumar, L.; Agarwal, S.; Singh, T.; et al. (2014): "Patterns of head injury at tertiary care hospital". International Journal of Scientific Study, 1(5):5-8.

Mahdian, M.; Fazel, M.R.; Sehat, M.; et al. (2017): "Epidemiological profile of extremity fractures and dislocations in road traffic accidents in Kashan, Iran: a glance at the related disabilities". Arch Bone Jt Surg., 5(3):186-192.

Meel, B.L. (2007): "Trends in fatal motor vehicle accidents in Transkei region of South Africa". Med. Sci. Law, 47:64-68.

Nantulya, V.M. and Reich, M. R. (2002): "The neglected epidemic: road traffic injuries in developing countries". British Medical Journal, 324(7346): 1139-1141.

Nishitani, Y.; Okazaki, S.; Suzuki, K.; et al. (2009): "The discrepant severity of external and internal injuries in a traffic accident: the cushioning effect via a human body against direct impact: autopsy cases". Am. J. Forensic Med. Pathol., 30(2):186-187.

Patil, S.S.; Kakade, R.; Durgawale, P.; et al. (2008): "Pattern of road traffic injuries: a study from Western Maharashtra". Indian J. Community Med., 33(1):56-57.

Peden, M. and Sminkey, L. (2004): "World Health Organization dedicates World Health Day to road safety". Inj. Prev., 10(2):67.

Salgado, M.S. and Colombage, S.M. (1988): "Analysis of fatalities in road accidents". Forensic Sci. Int., 36:91-96.

Shotar, A.M.; Alzyoud, S.A.; Obeidat, J.; et al. (2014): "Road traffic accidents 
casualties in the north of Jordan: an epidemiological study". European Scientific Journal, 10(26):262-268.

Siddaramanna, T. C. and Kumar, D.R. (2014): "Retrospective Study of Pattern of External Injuries in Road Traffic Accidents". International Journal of Biomedical and Advance Research, 05(09):451-453.
Singh, R.; Singh, H.K.; Gupta, S.C.; et al. (2014): "Pattern, severity and circumtances of injuries sustained in road traffic accidents: a tertiary care hospitalbased study". Indian J. Community Med., 39(1):30-34.

World Health Organization (WHO) (2018): Global status reports on road safety, Geneva, Switzerland. 


\section{دراسة طبية شرعية لحالات حوادث الطرق المرورية التي تم دخولها لمستشفى المثيا الجامعي}

\section{رحاب حسني عبل الكريم يونس و رانا عادل عمار المصري}

قسم الطب الثرعي والسموم الإكلينيكية ، كلية الطب، جامعة المنيا

تشكل حوادث الطرف مشكلة صحية عامة كبيرة ، فهي ترتفع بمعدل ينذر بالخطر وتتسبب في زيادة معدل

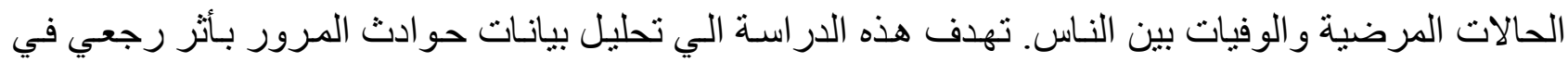

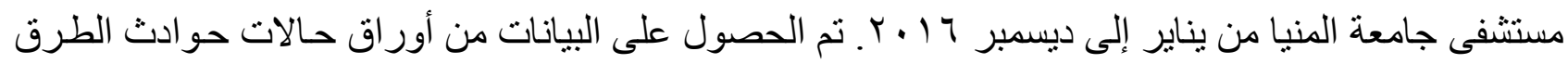

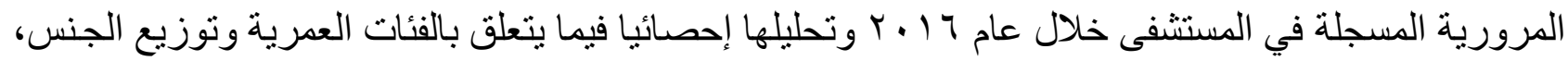
و المركبة المسببة ، ونمط الإصابات ، و الاختلاف الموسمي ، بالإضـافة الي عدد الوفيات ، و الأسباب الرئيسية

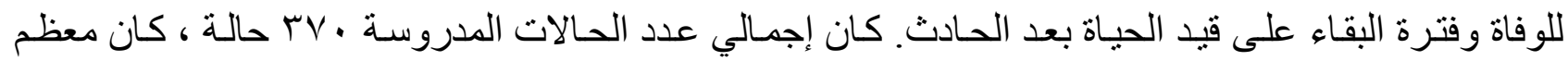

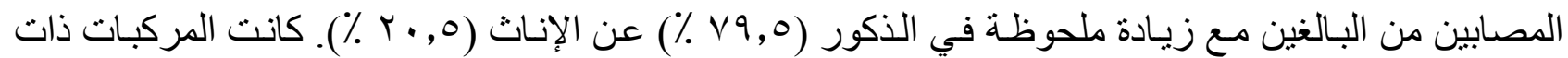

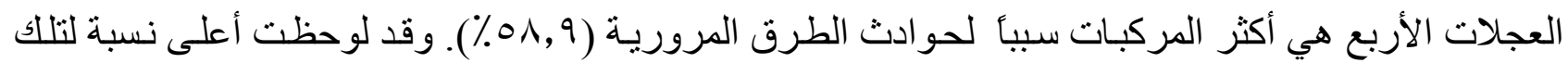

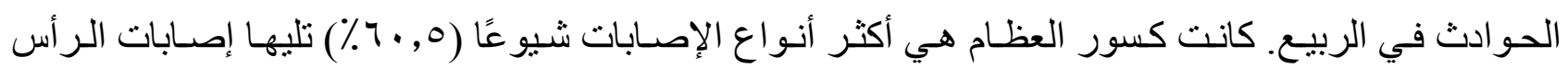

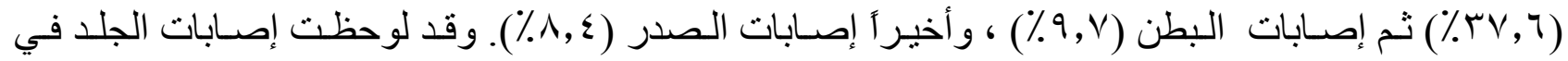

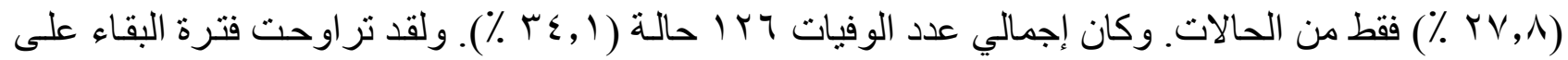
قيد الحياة بعد الحادث من صفر الي احدي عشر يوما؛ كانت إصابات الر أس الأكثر شيو عًا في حالات الوفاة فقد

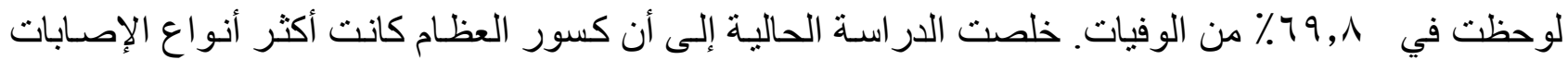
شيو عًا في حالات حوادث الطرق المرورية، بينما كانت إصابات الر أس هي العامل الرئيسي المساهم في الوفاة. بالإضافة الي أن إصابة الجلد ليست مؤشرا على شدة الإصابة الداخلية. 